\title{
The Effect of Focus on Form and Task Complexity on L2 Learners' Oral Task Performance
}

\author{
Asghar Salimi \\ English Department, Faculty of Humanities, University of Maragheh, Maragheh, Iran \\ E-mail: Asgharsalimi356@gmail.com
}

Doi:10.7575/aiac.alls.v.6n.6p.54

URL: http://dx.doi.org/10.7575/aiac.alls.v.6n.6p.54
Received: 19/06/2015

Accepted: 01/09/2015

\begin{abstract}
Second Language learners' oral task performance has been one of interesting and research generating areas of investigations in the field of second language acquisition specially, task-based language teaching and learning. The main purpose of the present study is to investigate the effect of focus on form and task complexity on L2 learners' oral task accuracy. To this end, sixty intermediate learners of English as a foreign language attending an English institute were chosen as the participant of the study and were divided into three groups control and two experimental groups with and without focus on form strategy. ANOVA and Independent Sample T-test were employed as the statistical means of analysis. The results a of analysis revealed significant differences among the performance of the groups. The study carries significant implications for syllabus and task designers, curriculum developers and language teachers.
\end{abstract}

Keywords: Accuracy, Focus on form, Task, Task-based language teaching, Task complexity

\section{Introduction}

Many students encounter unique problems in their study of English. One of the problems that most foreign language learners, including English language learners, encounter in their process of language learning is attaining a satisfactory level of oral production. This may be due to different reasons such as anxiety, low self-esteem, high affective filter, task features etc. Few studies have been conducted designed to offer solutions to the problem and improve the students' proficiency in English. The researcher proposed using a procedure based on the use of tasks as the central part of planning and instruction in language teaching called Task-Based language Teaching (TBLT) to enhance the oral performance of EFL learners. TBLT puts tasks at the center of the methodological focus. It views the learning process as a set of communicative tasks that are directly linked to the curricular goals they perform. As a recent development in the field of second language (L2) teaching, Task-Based Language Teaching (TBLT) has inspired a lot of pedagogical innovations and theoretical investigations among L2 teachers and researchers. Today, language teachers look upon TBLT as a fruitful approach to L2 instruction that has the potentiality to provide them with new insights into the most effective ways an L2 can be taught. It is hypothesized that task features have some positive or negative impact on learners` performance in terms of accuracy, fluency, and complexity.

The role that tasks play has important place for some researchers in the field of second language acquisition who are interested in developing pedagogical application of second language acquisition theory. A central issue in TBLT involves the impact of task complexity on L2 learners' performance. L2 researchers have begun a research to test the frequent claims that helps to support of TBLT. They have accepted experiments to investigate whether the superiority of TBLT over more traditional approaches to language teaching and learning can be supported by research findings, what are learners' attitudes towards task-based pedagogy, how TBLT can be employed to improve learners' language skills (i.e., listening, speaking, reading, and writing), what cognitive processes are involved in task performance, etc. Of these research topics, the most flourishing one has centered on the question of what factors increase the difficulty with which L2 learners perform and process pedagogical tasks. Besides, focus on form within TBLT has received a lot of attention in literature and research since 1990s.However, there are paucity of research to have investigated the joint investigation of the effects of task cognitive complexity and focus on form on L2 learners' oral task performance in terms of accuracy, fluency and complexity. The main purpose of the present study is to investigate the effect of focus on form and task complexity on L2 learners' oral task accuracy.

\section{Literature Review}

One of the main issued in TBLT is how to define and determine the complexity of a task. This is of importance since this kind of knowledge can contribute language teachers have a better understanding of task performance, design, and development. As (Robinson, 2001) argues, task complexity "is the result of the attentional, memory, reasoning, and other information processing demands imposed by the structure of the task on the language learner" (p. 28). Moreover, task complexity can affect grading and sequencing decisions in a language teaching syllabus.

Task complexity is derived from the cognitive demands of a task makes in the conceptualization phase. This is based upon the idea that intricate concepts require using grammatically complex structures, and therefore cognitively complex 
tasks are complex both in terms of conceptualization and linguistic formulation. However, tasks may make various complexity demands on the conceptualization and formulation phases. As in specific occasions, ordering tasks in terms of cognitive complexity can be difficult since tasks might make different demands on different phases of language performance.

A central issue in task-based language learning is that, while performing a task, learners need to coordinate the amount attention they allocate to different aspects of the task in order to meet the linguistic demands of the task. Such a view raises questions concerning how attentional resources can be used, coordinated and directed to different aspects of language production during task completion.

There are two important models of task complexity in field of TBLT as following:

1) Skehan and Foster's (2001) Limited Attentional Capacity Model and

2) Robinson's $(2001,2005)$ Cognition Hypothesis.

In their model, Skehan and Foster (2001) consider attention and memory as limited in capacity. They argue that the increase of task complexity will lead to the reduction of available amount of attention and memory resources. Therefore, some aspects of performance will be attended while others will not. In addition, they sate that cognitively more demanding tasks draw learners' attention away from linguistic forms.

However, Robinson $(2001,2005 \mathrm{~b})$ argues that attention is related to voluntary regulation. This model states that ordering tasks from cognitively simple to complex allows learners to performing real-world tasks successfully. This model supports the idea that increasing task's cognitive load and processing complexity will lead to increase in the accuracy and complexity but not the fluency.

This study is based on Sheehan's model. Skehan (1998) suggested a three-way distinction for the analysis of task difficulty as following:

1) Code complexity (vocabulary load and variety; linguistic complexity and variety);

2) Cognitive complexity (familiarity of topic, discourse or task; amount of computation and organization, and sufficiency of information

3) Communicative stress (time pressure; scale; number of participants; length of text; modality; stakes; opportunity for control);

Also, they later added learner factors (intelligence; breadth of imagination; personal experience) to this taxonomy.

Furthermore, as Long (1996) argued focus on form is mainly motivated by, Schmidt's (1990) noticing hypothesis. Schmidt stated that noticing is a cognitive process that involves attending to the input learners receive and is inevitably a conscious process. He proposed that it is a necessary condition for second language learning.

Schmidt (2001) has argued that attention correlates two vital stages for second language acquisition as following:

1) Noticing, i.e. registering formal features in the input,

2) Noticing the gap, i.e. identifying how the input to which the learner is exposed differs from the output the learner is able to generate

This study set out to investigate the effect of focus on form and task complexity on EFL learners 'oral task performance in terms of accuracy.

\subsection{Studies conducted on task complexity and focus on form}

Skehan and Foster (1999) investigated the effects of task structure and processing load on L2 learners' performance on a narrative retelling task. They found that the structured task generated more fluent speech in all four conditions. Ishikawa (2006) studied the impacts of task complexity and language proficiency on L2 written narrative production. He considered four modes of production as dependent variables namely accuracy, structural complexity, lexical complexity, and fluency. He found that the low-proficiency learners seemed benefited more when task complexity was manipulated from here-and-now to there-and-then. Rahimpour (2007) investigated the impact of task complexity on L2 learners' oral performance. He reported that there-and-then task led to more accuracy while here-and-now task led to more complexity. He also found that here-and-now task led to more fluency than there-and-then task. Kuiken and Vedder (2008) conducted a study on university students who performed two writing tasks with different cognitive complexity. The students were divided into low- and high-proficiency groups. They implemented linguistic performance in terms of syntactic complexity, lexical variation, and accuracy. They concluded that (a) with regard to syntactic complexity and lexical variation, hardly any significant differences were found between the complex and noncomplex tasks; (b) no interaction of task type and proficiency level could be observed. Hosseini and Rahimpour (2010) explored the effects of task complexity on L2 learners' written performance on narrative pictorial tasks of here-and- now and there-and then. They found that cognitively more demanding tasks led to more fluency, but not accuracy and complexity. Rezazadeh, Tavakoli, and Eslami-Rasekh (2011), investigated the role of task type in foreign language written production in terms of accuracy, fluency, and complexity. They used two types of tasks (instruction task and an argumentative task) used in the study. They concluded that learners in the instruction-task group performed significantly better than those in argumentative-task group in terms of accuracy, fluency, and complexity. Salimi et al (2011) investigated the effect of task complexity on L2 learners' written performance. They found out that task complexity did not have a significant effect on accuracy. Regarding the accuracy and fluency of written production, it 
was revealed that task complexity had a significant effect on accuracy and fluency of the learners. For complexity of written production, they found that L2 learners' written complexity was significantly affected by task complexity. Salimi and Dadashpour (2012b) conducted a study to find out the effect of task complexity on L2 learners' language production. Their study was based on the comparison of two models of task complexity namely Robinson's cognition hypothesis and Skehan's trade-off model. They found out that task complexity led to an increase in the domains of fluency and complexity but not accuracy. Salimi, Alavinia, and Hosseini (2012) investigated the effects of strategic pretask planning and task complexity on L2 learners' written performance in terms of accuracy. The findings of the study revealed that pre-task strategic planning time in both simple and complex task led to more accuracy.

As Ellis (2009) argues, "the only characteristic common among all task-based approaches is the inclusion of a focus on form" (p. 225). Moreover, advocates of task-based language teaching "do not view attention to form as an optional element of task-based language teaching, but as necessary to ensure 'noticing', which Schmidt (1994) viewed as a requisite for acquisition to take place" (p. 232, emphasis added).

Focus on form techniques are essential parts of task-based language teaching, just as tasks are an ideal environment for cultivating focus on form. As proponents of Focus on Forms, Long and Crookes (1992, p.43) pointed out that "tasks provide a vehicle for the presentation of appropriate target language samples to learners-input which they will inevitably reshape via application of general cognitive processing capacities and for the delivery of comprehension and production opportunities of negotiable difficulty". Furthermore, according to a more SLA perspective to advocacy of TBT, issues such as learn ability, the order of acquisition of particular L2 structures, and the implications of the input, interaction and output hypothesis are central issues (Lynch \& MacLean, 2000).

One of the most important issues in research on language learning tasks concerns the interaction between task complexity and focus on form. Previous studies on the effects of task complexity have largely addressed such issues as L2 written production (Kuiken \&Vedder, 2008), fluency and lexical complexity (Ong \& Zhang, 2010), etc. Reviewing previous research makes it clear that there are only a few studies which examined both the effects of Focus on Form and Task complexity, most of the researches are about just Focus on form or only about Task complexity. The present study intends to fill this gap by examining how task complexity combined with focus on form affects EFL learners' oral performance.

\subsection{Research question and hypothesis}

The above literature review yielded the following research question and research hypotheses:

RQ1: What are the effects of Focus on form and Task complexity on L2 learners' oral performance in terms of accuracy?

\section{Research hypotheses}

H1: Learners receiving Focus on form will outperform group who do not receive any Focus on form in terms of accuracy in simple and complex tasks.

\section{Methodology}

\subsection{Participants and setting}

The participants of the study were 6o Iranian male EFL learners, who had been in upper intermediate level of language proficiency in English. The participants were studying in Jihad Daneshgahi Language Institute in Tabriz. The participants were from different L1 backgrounds, including Turkish and Persian. They aged between 18- 25 and had been studying English in that institute for about three years. They were randomly selected on the basis of their performance on Oxford Proficiency Test (OPT) (2004) which was administered among the learners of intermediate and upper-intermediate of the institute to make sure about the proficiency level of the learners prior the experiment. They were randomly separated in half into two groups of simple and complex. Then, each group was divided into two control and experimental groups as following: simple experimental (simple task with focus on form), simple control (simple task without focus on form), complex experimental (complex task with focus on form), and complex control (complex task without focus on form). In order to control the variables of gender, all males who had obtained the criteria were included in the study.

\subsection{Instructional material}

The participants of the study received instruction from 5 units of Four Corners 3 by Richards and Bohlke (2012). These books are commonly used in language institutes all over the country to teach English as foreign or second language. They are written on the basis of communicative and task-based approaches to language teaching and learning.

\subsection{Data Collection Material}

A pictorial valid decision making tasks (one simple and the other complex task) were extracted from Gilabert 2007; Salimi Asadollahfam, and Dadashpour, 2010). A simplified "fire chief task" used in cognitive psychology was utilized. In this task, the learners were presented with a building where a fire has broken and where a number of people need to be rescued. The problem in the complex version required from learners not just one decision, but a long series simultaneously. In both versions of the task learners were instructed to specify the actions they would take to determine the order of their actions and justify their option for actions and specific order. In the simple task, there are similar types of people (i. e people with no particular roles) in the building who were faced with similar degrees of danger, the fire being relatively static, and the smoke blowing away from the building. In the complex one, learners had to deal with 
specific types of people (e.g. a pregnant woman, an elderly man, an injured person, a hero, etc). The factors in the task are also intricately related and dynamic (e.g. the different fires moving towards the people and the smoke blowing into building through the ventilation system) and they have fewer resources (i.e. a single fire truck), which is thought would force learners to prioritize, and later justify their actions (Gilabert, 2007).

\subsection{Procedure}

First the researcher chose upper intermediate level classes at Jihad Daneshgahi institute in Tabriz branch and administered OPT (2004) in order to make sure that participants are at the same level of proficiency. Based on the results of the OPT (2004), 60 students out of 100 students were chosen as the participants of the study. The participants were then randomly classified into two groups simple and complex, thirty in each group. Then, they were participants of each group were divided into two control and experimental groups as following: simple experimental (simple task with focus on form), simple control (simple task without focus on form), complex experimental (complex task with focus on form), and complex control (complex task without focus on form). The participants of experimental groups received form-focused instruction. That is, they were taught on the basis of the principles and strategies of focus on form. When the teacher wanted to teach them a new grammatical point, she did not teach them directly, rather she tried to draw the learners' attention to newly presented structure implicitly by highlighting it on the board or providing ample amount of examples. However, in the control groups, the learners were taught based on the traditional method of teaching or focus on forms, i.e. they were instructed based on the principles of the traditional approach of PPP (presentation-practiceproduction). In these groups, when the teacher wanted to present a new grammatical form, she explained the new points of grammar directly to the learners. All the groups received instruction for a semester of eighteen sessions during summer course in 2014. At the end of the treatment, the participants of all groups were given the simple version of the decision-making task to perform it. After two weeks of interval the participants were given complex version of the same decision-making fire task. Their oral task performances were recorded with a tape recorder by the researcher. After that, the oral performances of the participants were transcribed and measured by the researcher on the basis of the measures of accuracy, complexity, and fluency proposed by Ellis (2003). In order to ensure about the reliability of the quantification of the oral data, they were re-quantified by another M.A in TEFL who was familiar with issues involved in the research.

\section{Data Analysis and Results}

To compare the means of accuracy of two groups, appropriate statistical means of analysis were run and the results are presented as the following:

\subsection{Independent-Samples T-test of accuracy of complex task with and without focus on form}

Table 4.1 shows the mean differences of accuracy of learners' oral task performance in complex task with and without focus on form.

Table 4.1 The mean differences of accuracy of accuracy of learners' oral task performance in complex task with and without focus on form

\begin{tabular}{lccc}
\hline & $\mathrm{N}$ & Mean & Std. Deviation \\
\hline $\begin{array}{l}\text { Complex } \\
+ \text { FOF }\end{array}$ & 15 & 0.84 & 0.12 \\
\hline $\begin{array}{l}\text { Complex - } \\
\text { FOF }\end{array}$ & 15 & 0.79 & 0.17 \\
\hline
\end{tabular}

According to table 4.1, the mean of oral accuracy of the participants receiving focus on form instruction in complex task (0.84) is higher than the learners who did not receive form-focused instruction (0.79). That is, learners who were taught on the basis of focus on form strategies produced more accurate oral language than learners who received traditional instruction.

Figure 4.1 clearly shows the mean differences of accuracy of learners' oral task performance in complex task with and without focus on form.

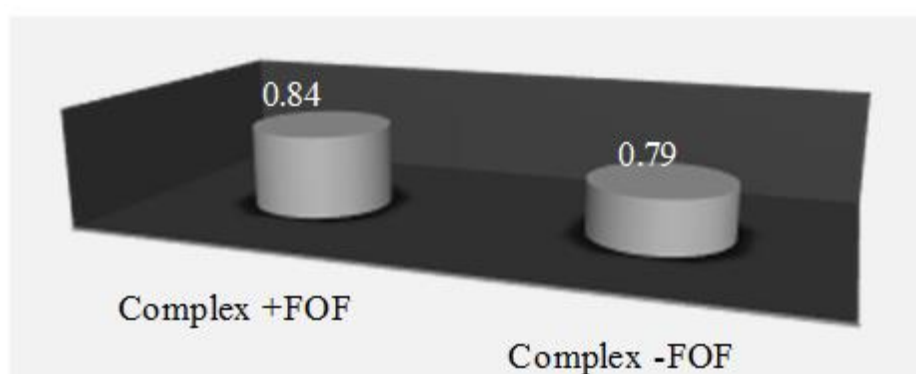

Figure 4.1 The mean differences of accuracy of learners' oral task performance in complex task with and without focus on form

The results of the Independent Samples-T-test for comparing the means of accuracy of learners' oral task performance in complex task with and without focus on form are provided in table 4.2. 
Table 4.2 Independent Samples T-Test for the means of accuracy of learners' oral task performance in complex task with and without focus on form

\begin{tabular}{|c|c|c|c|c|c|c|c|c|c|}
\hline & \multicolumn{2}{|c|}{$\begin{array}{l}\text { Levene's Test } \\
\text { for Equality of } \\
\text { Variances }\end{array}$} & \multicolumn{7}{|c|}{ T-test Equality of Means } \\
\hline & \multirow[t]{2}{*}{$\mathrm{F}$} & \multirow[t]{2}{*}{ Sig. } & \multirow[t]{2}{*}{$\mathrm{t}$} & \multirow[t]{2}{*}{$\mathrm{df}$} & \multirow[t]{2}{*}{$\begin{array}{l}\text { Sig (2- } \\
\text { tailed) }\end{array}$} & \multirow[t]{2}{*}{$\begin{array}{l}\text { Mean } \\
\text { Differen } \\
\text { ce }\end{array}$} & \multirow{2}{*}{$\begin{array}{c}\text { Std. } \\
\text { Error } \\
\text { Differen } \\
\text { ce }\end{array}$} & \multicolumn{2}{|c|}{$\begin{array}{l}\text { 95\% Confidence } \\
\text { Interval of the } \\
\text { Difference }\end{array}$} \\
\hline & & & & & & & & $\begin{array}{c}\text { Lowe } \\
\mathrm{r}\end{array}$ & Upper \\
\hline $\begin{array}{l}\text { Equal variances } \\
\text { assumed }\end{array}$ & 1.77 & 0.19 & 0.97 & 28 & 0.33 & 0.05 & 0.05 & -0.05 & 0.16 \\
\hline $\begin{array}{l}\text { Equal variances } \\
\text { not assumed }\end{array}$ & & & 0.97 & 25.59 & 0.33 & 0.05 & 0.05 & -0.05 & 0.16 \\
\hline
\end{tabular}

The results of applying Independent Samples T-test for comparing the means of accuracy of learners' oral task performance in complex task with and without focus on form were provided in the above table. According to the data presented in the table, the learners receiving form-focused instruction outperformed the learners who did not receive focus on form instruction in terms of accuracy of their oral task production.

4.2 Independent-Samples T-test of accuracy of simple task with and without focus on form

Table 4.3 shows the mean differences of accuracy of simple task with and without focus on form.

Table 4.3 The mean differences of accuracy of accuracy of learners' oral task performance in simple task with and without focus on form

\begin{tabular}{lccc}
\hline & N & Mean & $\begin{array}{c}\text { Std. } \\
\text { Deviation }\end{array}$ \\
\hline Simple +FOF & 15 & 0.82 & 0.10 \\
\hline Simple -FOF & 15 & 0.77 & 0.13 \\
\hline
\end{tabular}

As the data presented in the above table show, the learners receiving focus on form instruction produced more accurate language $(0.82)$ than the learners receiving focus on forms instruction $(0.77)$ in their oral production in simple task. This means that learners who were instructed according to focus on form strategies performed better than the others in terms of oral accuracy in simple task.

Figure 4.2 clearly shows the mean differences of accuracy of learners' oral task performance in simple task with and without focus on form.

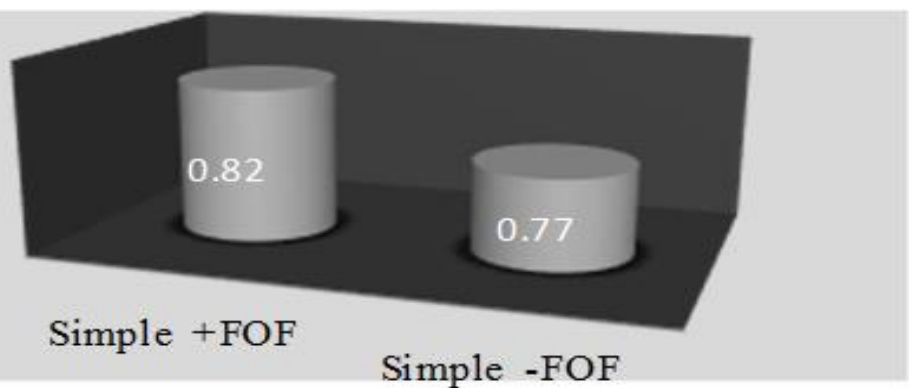

Figure 4.2 The mean differences of accuracy of learners' oral task performance in simple task with and without focus on form

The results of the Independent Samples-T-test for comparing the means of accuracy of learners' oral task performance in simple task with and without focus on form are provided in table 4.4.

Table 4.4 Independent Samples T-Test for the means of accuracy of learners' oral task performance in simple task with and without focus on form

\begin{tabular}{|c|c|c|c|c|c|c|c|c|c|}
\hline & \multicolumn{2}{|c|}{$\begin{array}{l}\text { Levene's Test } \\
\text { for Equality of } \\
\text { Variances }\end{array}$} & \multicolumn{7}{|c|}{ T-test Equality of Means } \\
\hline & \multirow[t]{2}{*}{$\mathrm{F}$} & \multirow[t]{2}{*}{ Sig. } & \multirow[t]{2}{*}{$\mathrm{t}$} & \multirow[t]{2}{*}{$\mathrm{df}$} & \multirow[t]{2}{*}{$\begin{array}{l}\text { Sig (2- } \\
\text { tailed) }\end{array}$} & \multirow[t]{2}{*}{$\begin{array}{c}\text { Mean } \\
\text { Difference }\end{array}$} & \multirow[t]{2}{*}{$\begin{array}{l}\text { Std. Error } \\
\text { Difference }\end{array}$} & \multicolumn{2}{|c|}{$\begin{array}{l}\text { 95\% Confidence } \\
\text { Interval of the } \\
\text { Difference }\end{array}$} \\
\hline & & & & & & & & Lower & Upper \\
\hline $\begin{array}{l}\text { Equal variances } \\
\text { assumed }\end{array}$ & 1.59 & 0.21 & 1.07 & 28 & 0.29 & 0.04 & 0.04 & -0.04 & 0.13 \\
\hline $\begin{array}{l}\text { Equal variances } \\
\text { not assumed }\end{array}$ & & & 1.07 & 26.12 & 0.29 & 0.04 & 0.04 & -0.04 & 0.13 \\
\hline
\end{tabular}


The results of applying Independent Samples T-test for comparing the means of accuracy of learners' oral task performance in simple task with and without focus on form were provided in the above table. As the data presented in the table show, the learners receiving form-focused instruction outperformed the learners who did not receive focus on form instruction in terms of accuracy of their oral task production in simple task.

\subsection{Independent-Samples T-test of accuracy of simple and complex tasks with focus on form}

The mean differences of accuracy of simple and complex tasks with focus on form are provided in the following table.

Table 4.5 The mean differences of accuracy of accuracy of learners' oral task performance in simple and complex tasks with focus on form

\begin{tabular}{lccc}
\hline & N & Mean & Std. Deviation \\
\hline Simple +FOF & 15 & 0.82 & 0.10 \\
\hline $\begin{array}{l}\text { Complex+ } \\
\text { FOF }\end{array}$ & 15 & 0.84 & 0.12 \\
\hline
\end{tabular}

According to the data provided in table 4.5, the learners who were taught according to form-focused instruction strategies produced more accurate language (0.84) in complex task than simple task $(0.82)$, i.e. learners receiving focus on form in complex task outperformed learners receiving the same instruction in simple task.

Figure 4.3 vividly indicates the mean differences of accuracy of learners' oral task performance in simple and complex tasks with focus on form.

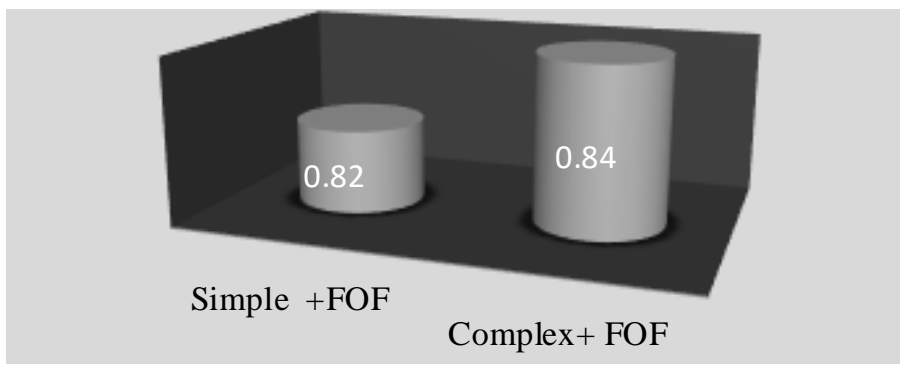

Figure 4.3 The mean differences of accuracy of learners' oral task performance in simple and complex tasks with focus on form

Table 4.6 shows the results of the Independent Samples-T-test for comparing the means of accuracy of learners' oral task performance in simple and complex tasks with focus on form.

Table 4.6 Independent Samples T-Test for the means of accuracy of learners' oral task performance in simple and complex tasks with focus on form

\begin{tabular}{|c|c|c|c|c|c|c|c|c|c|}
\hline & \multicolumn{2}{|c|}{$\begin{array}{c}\text { Levene's Test } \\
\text { for Equality of } \\
\text { Variances }\end{array}$} & \multicolumn{7}{|c|}{ T-test Equality of Means } \\
\hline & \multirow[t]{2}{*}{$\mathrm{F}$} & \multirow[t]{2}{*}{ Sig. } & \multirow[t]{2}{*}{$\mathrm{t}$} & \multirow[t]{2}{*}{ df } & \multirow[t]{2}{*}{$\begin{array}{l}\text { Sig }(2- \\
\text { tailed })\end{array}$} & \multirow[t]{2}{*}{$\begin{array}{c}\text { Mean } \\
\text { Difference }\end{array}$} & \multirow[t]{2}{*}{$\begin{array}{l}\text { Std. Error } \\
\text { Difference }\end{array}$} & \multicolumn{2}{|c|}{$\begin{array}{l}95 \% \text { Confidence } \\
\text { Interval of the } \\
\text { Difference }\end{array}$} \\
\hline & & & & & & & & $\begin{array}{c}\text { Lowe } \\
\mathrm{r}\end{array}$ & $\begin{array}{c}\text { Uppe } \\
\text { r }\end{array}$ \\
\hline $\begin{array}{l}\text { Equal variances } \\
\text { assumed }\end{array}$ & 1.36 & 0.25 & -0.64 & 28 & 0.52 & -0.02 & 0.04 & -0.11 & 0.05 \\
\hline $\begin{array}{l}\text { Equal variances not } \\
\text { assumed }\end{array}$ & & & -0.64 & 26.89 & 0.52 & -0.02 & 0.04 & -0.11 & 0.05 \\
\hline
\end{tabular}

Table 4.6 presents the results of applying Independent Samples T-test for comparing the means of accuracy of learners' oral task performance in simple task with and without focus on form. According to the data presented in the table, the learners receiving form-focused instruction produced slightly more accurate language in complex task than the learners who received the same instruction in simple task. 


\subsection{The comparison of the means of fluency of simple and complex tasks with and without focus on form}

One-Way ANOVA was employed to compare the means of fluency of simple and complex tasks with and without focus on form. The results of the analysis are provided in the following table.

Table 4.7 The results of One-Way ANOVA for the comparison of the means of fluency of simple and complex tasks with and without focus on form

\begin{tabular}{lccccc}
\hline & $\begin{array}{c}\text { Sum of } \\
\text { Squares }\end{array}$ & df & Square & F & Sig. \\
\hline $\begin{array}{l}\text { Between } \\
\text { Groups }\end{array}$ & 2112.49 & 3 & 704.16 & 2.27 & 0.09 \\
\hline Within & & & & & \\
Groups & 17364.25 & 56 & 310.07 & & \\
\hline Total & & & & & \\
\hline
\end{tabular}

The data presented in table 4.23 shows that there was a meaningful difference between the performances of the participants who received and did not receive focus on form instruction in simple and complex tasks in terms of fluency of their oral task performance.

The mean differences of the four groups of learners in simple and complex tasks with and without focus on form are presented in the following figure.

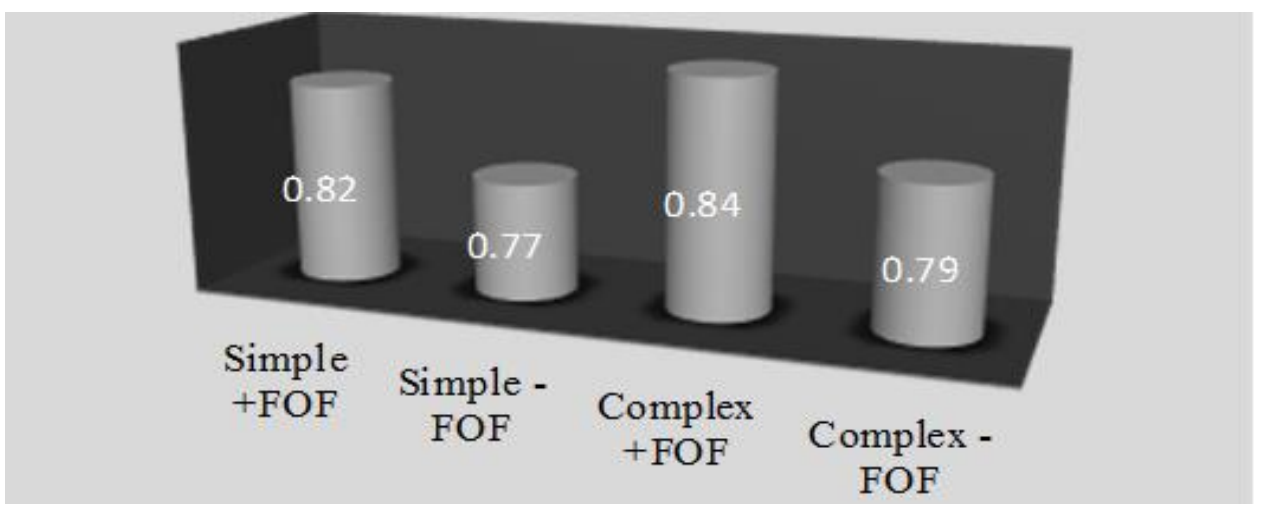

Figure 4.4 The mean differences of accuracy of simple and complex tasks with and without focus on form

This means that focus on form and task complexity had significant effects on the L2 learners' oral task performances in terms of accuracy.

\section{Discussion and Conclusion}

The effects of task complexity and focus on from on the accuracy of L2 learners' oral task performance was explored as part of this study. The results of the data analysis regarding the oral accuracy of the learners were provided in chapter four in tables 4.2, 4.4, 4.6, and 4.8 and figures 4.1, 4.2, 4.3, and 4.4. The finding of the study revealed that there were significant differences between the oral performances of the learners who received focus on form instruction and those who received traditional instruction both in simple and complex tasks. According to the findings of this study, the most accurate language was related to the learners who received focus on form instruction on complex task while the least accurate language was for the learners who received traditional instruction on simple task. That is, task complexity and focus on form were effective on the oral task production of the learners in terms of accuracy.

The findings of this study in terms of accuracy are in line with the findings of Kuiken, Mos and Vedder (2005), Rahimpour (2007), Kuiken and Vedder (2008), and Hejazi (2012). Kuiken, Mos and Vedder (2005) manipulated task complexity by varying the number of elements to be considered in a writing task. Specifically, they asked Dutch learners of Italian with high and low proficiency levels to write a recommendation letter to a friend about where to visit for a holiday. Five destination choices were given and the participants were required to choose only one based on a varying number of criteria (i.e., three in the simple and six in the complex task). They examined three categories of L2 production measures: syntactic complexity; lexical variation; accuracy. Their results showed that there were no task complexity effects on lexical and syntactic complexity. In contrast, analyses on accuracy data yielded significant interactions between task complexity and proficiency; namely, greater written accuracy was observed when task complexity and proficiency were both high. Rahimpour (2007) studied the effect of task complexity on L2 learners' oral performance. The results showed that there-and-then task (complex task) led to more accuracy.

However, the finding of the present study in terms of accuracy ran against the findings of Hosseini and Rahimpour (2010), Salimi et al (2011), and Salimi and Dadashpour (2012). Hosseini and Rahimpour (2010) investigated the effects of task complexity on L2 learners' written performance on narrative pictorial tasks of here-and- now and there-and then. 
The results of the study demonstrated that cognitively more demanding task (there-and- then) had no significant effects on accuracy. Salimi et al (2011) investigated the effect of task complexity on L2 learners' written performance. They found out that task complexity did not have a significant effect on accuracy. Salimi and Dadashpour (2012) conducted a study to find out the effect of task complexity on L2 learners' language production. Their study was based on the comparison of two models of task complexity namely Robinson's Cognition Hypothesis and Skehan's Trade-off Model. They found out that task complexity led to an increase in the domains of fluency and complexity but not accuracy.

The findings of this study in terms of accuracy can be attributed to the limited attention model proposed by Skehan and Foster (2001). Skehan and Foster's (2001) limited attentional capacity model views attention and memory as limited in capacity; therefore, they suggest that increasing task complexity reduces the pool of available attention and memory resources. As a result, some aspects of performance will be attended to while others will not. Skehan and Foster (2001) also claim that cognitively more demanding tasks draw learners' attention away from linguistic forms so that enough attention need to the content of the message. Also, the findings of the study can be imputed to Schmidt's noticing hypothesis (Schmidt, 1990, 2001). This hypothesis holds that noticing, a cognitive process that involves attending to the input learners receive, is inevitably a conscious process and is a necessary condition for second language learning. Schmidt $(1990,2001)$ has argued that attention and its subjective correlates noticing, i.e. registering formal features in the input, and noticing the gap, i.e. identifying how the input to which the learner is exposed differs from the output the learner is able to generate, are essential processes in L2 acquisition. Attention is generally considered a necessary condition for changing input into intake in the field of SLA (Schmidt, 1990, 2001). Nothing in the target language is available for intake into a learner's existing system unless it is consciously noticed.

It can be concluded that engaging learners in the performance of tasks with high amount cognitive complexity along with form-focused instruction can make learners' attentional resources be drawn more to the linguistic forms of the language and as a result of this, they produce. It can be said the more the complexity of the task, the more the learners' efforts to have more accurate production.

\subsection{Pedagogical Implications}

The findings of the present study may be helpful for second/foreign language researchers, language teachers, and syllabus and task designers. The findings of this study can add some new points to the literature of SLA and may provide the researchers of second language acquisition with some new insights and findings. Language teachers may benefit from the results of this study in that they can employ the strategies of form-focused instruction in their classes to improve their teaching and student's learning. Also, they can employ tasks with different complexity levels and demands to make their learners produce and learn language. Syllabus designers can use the findings of this study to design their syllabuses in ways that they involve task with different levels of task complexity and cognitive demands as well as they lend themselves to strategies of form.

\section{References}

Doughty, C. (2001). 'Cognitive underpinning of focus on form' In P. Robinson(Ed.). Cognition and second language instruction. Cambridge: Cambridge University press.

Ellis, R. (2003). Task-based language learning and teaching. Oxford: Oxford University Press.

Ellis, R. (2009). Task-based language teaching: Sorting out the misunderstandings. International Journal of Applied Linguistics 19 (3), 229-246.

Foster, P. (1999). Task-based learning and pedagogy. ELT Journal, 53(1), 69-70.

Foster, P., \& Skehan, P. (1996). The influence of planning and task type on second language performance. Studies in Second Language Acquisition, 9, 12-20.

Foster, P., \& Skehan, P. (1999). The influence of planning and focus of planning on task-based performance. Language Teaching Research, 3, 215-247.

Gilabert, R. (2005). Task complexity and L2 narrative oral production. Unpublished Ph.D. dissertation. University of Barcelona, Spain.

Gilabert, R. (2007). Effects of manipulating task complexity on self-repairs during L2 oral production. International Review of Applied Linguistics, 45, 215-240.

Hejazi, M. (2012). Teacher's error correction: A key factor in developing Iranian EFL learners' speech accuracy. Theory and Practice in Language Studies, 2(3), 619-624.

Hosseini, P. \& Rahimpour, M. (2010). The Impact of Task Complexity on L2 Learners' Written Narratives. CCSE, 3 (3), 198-205.

Ishikawa, T. (2006). The effects of task complexity and language proficiency on task-based language performance. The Journal of Asia TEFL, 3(4), 193-225.

Kuiken, F., Mos, M. \&Vedder, I. (2005). Cognitive task complexity and second language writing performance. In Eurosla Yearbook 5, Susan H. Foster-Cohen, Maria del PilarGarcía Mayo and Jasone Cenoz(eds.), 195-222. Amsterdam: John Benjamins.

Kuiken, F., \& Vedder, I. (2007). Task complexity and measures of linguistic performance in L2 writing. International Review of Applied Linguistics, $\quad$ 45(3), 261-284. 
Kuiken, F., \& Vedder, I. (2008). Cognitive task complexity and written output in Italian and French as a foreign language. Journal of Second Language Writing, 17, 48-60.

Long, M. (1985). A role for instruction in second language acquisition: task-based language teaching. In K. Hyltenstam and M. Pienemann (Eds.), Modeling and assessing second language acquisition (pp.77-99). Clevedon: Multilingual Matters.

Long, M. H. (1996). The role of linguistic environment in second language acquisition. In W.C.Ritchie and T.K.Bhatia (Eds.). Handbook of second language acquisition. (pp.413-463). San Diego; Academic Press.

Lynch, T. \& J. Maclean. (2000). Exploring the benefits of task repetition and recycling for classroom language learning. Language Teaching Research, 4, 221-50.

Ong, J., \& Zhang, L.J. (2010). Effects of task complexity on the fluency and lexical complexity in EFL students' argumentative writing. Journal of Second Language Writing. Doi: 10.1016/J.JSLW

Prabhu, N.S. (1987). Second language pedagogy. Oxford University Press.

Rahimpour, M. (2007). Task complexity and variation in L2 learners' oral discourse. Working Papers in Language and Linguistics, University of Queensland, 1-9.

Rezazadeh, M., Tavakoli, M. \& Eslami-Rasekh, A. (2011). The Role of task type in foreign language written production: Focusing on fluency, complexity, and accuracy. International Education Studies, 4(2), 169-176.

Robinson, P. (2001). Task complexity, task difficulty, and task production: exploring interactions in a componential framework. Applied Linguistics, 22(1), 27-57.

Robinson, P. (2003). The cognition hypothesis, task design, and adult task-based language learning. Second Language Studies, 21(2), 45-105.

Robinson, P. (2005). Cognitive complexity and task sequencing: studies in a componential framework for second language task design. International Review of Applied Linguistics, 43, 1-32.

Robinson, P. (2007). Task complexity, theory of mind, and intentional reasoning: effects on L2 speech production, interaction, uptake and perceptions of task difficulty. International Review of Applied Linguistics, 45(3), 193-213.

Rosa, E, \& O'Neill, D. (1999). Explicitness, intake, and the issues of awareness: Another piece to the puzzle. Studies in Second Language Acquisition, 21, 511-553.

Salimi, A. \& Dadashpour, S. (2012a). Task complexity and SL development: Does task complexity matter? ProcediaSocial and Behavioral Sciences, 46, 726-735.

Salimi, A. \& Dadashpour, S. (2012b). Task Complexity and Language Production Dilemmas (Robinson's Cognition Hypothesis vs. Skehan's Trade-off Model). Procedia-Social and Behavioral Sciences, 46, 643-652.

Salimi, A., Alavinia, P., \& Hosseini, P. (2012). The effect of strategic planning time and task complexity on L2 written accuracy. Theory and Practice in Language Studies, 2 (11), 2398-2406.

Salimi, A. \& Yousefi, M. (2009). The effect of task complexity on L2 learners' uptake in EFL context. A paper presented at 7th International TELLSI Conference. University of Yazd, October, 20-22

Schmidt, R. (1990). The role of consciousness in second language learning. Applied linguistics, 11, 129-58.

Schmidt, R. (1994). Deconstructing consciousness in search of useful definitions for applied linguistics. AILA Review, $11,11-26$.

Schmidt, R. (2000). 'Attention" in P. Robinson (Ed.): Cognition and second language instruction. (PP. 3-32). Cambridge: Cambridge University Press.

Skehan, P. (1996). A framework for the implementation of task-based instruction. Applied Linguistics, 17(1), 38-62.

Skehan, P. (1998a). Task-based instruction. Annual Review of Applied Linguistics, 18, 268-286.

Skehan, P. (1998b). A cognitive approach to language learning. Oxford: Oxford University Press.

Skehan, P. (2003). Task-based instruction. Language Teaching, 36, 1-14.

Skehan, P. \& Foster, P. (1999). The influence of task structure and processing conditions on narrative retellings. Language Learning, 49(1), 93-120.

Skehan, P. \& Foster, P. (2001). Cognition and tasks. In P. Robinson (Ed.), Cognition and second language instruction (pp.183-205). Cambridge: Cambridge University Press.

Swain, M. (1998). 'Focus on form through conscious reflection' in C. Doughty and J. Williams (Eds.). pp: 64-81.

Van Patten, B. (1990). Attending to content and form in the input: an experiment in consciousness. Studies in Second Language Acquisition, 12, 287-301.

VanPatten, B. \& T. Cadierno. (1993). Explicit instruction and input processing. Studies in second Language Acquisition, 15, 225-41.

Willis, D., \& Willis, J. (2001). Task-based language learning. In R. Carter and D. Nunan (Eds.), The Cambridge guide to teaching English to speakers of other languages (pp.173-179). Cambridge: Cambridge University Press. 